\title{
Use of agricultural habitats by roe deer inhabiting a small forest area
}

\author{
Władysław AULAK and Joanna BABIŃSKA-WERKA
}

\begin{abstract}
Aulak W. and Babińska-Werka J. 1990. Use of agricultural habitats by roe deer inhabiting a small forest area. Acta theriol. 35: 121-127.

Faeces distribution analyses and direct observation of animals were employed to determine the range of use of agrocoenoses by the roe deer Capreolus capreolus (Linnaeus, 1758 ), inhabiting a small forest (about 200 ha) surrounded by fields. The highest roe deer pellet density and $2 / 3$ of the roe deer sighted were found in the zone $100-200 \mathrm{~m}$ from the forest tree-stand edge. The zone of roe deer penetration around the forest, calculated from pellet density decrease regression lines and decreasing numbers of grazing roe deer with a growing distance from the forest, was about $500 \mathrm{~m}$ wide.
\end{abstract}

Warsaw Agricultural University, Faculty of Forestry, Department of Game Management, Rakowiecka 26/30,02-528 Warsaw, Poland

Key words: use of agrocenoses, Capreolus capreolus, faeces distribution

\section{Introduction}

Roe deer Capreolus capreolus (Linnaeus, 1758) is a species that uses various habitats (Ellenberg 1975). It can inhabit large forest complexes, as well as best, unwooded field areas (Pielowski 1984). As demonstrated by Bluzma (1976), roe deer can be considered as an ecotone species whose individuals readily use, simultaneously, a forest and adjacent fields, thus increasing their density in small woods. According to the latter author, there exists a reverse relationship between the size of woodland area and roe deer density. This is confirmed by Aulak and Babińska-Werka (in prep.). As a results, in small woods surrounded by fields the abundance of roe deer is three times as high as the density level adopted by game management regulations for woodlands in Poland. These animals temporarily leave the forest, move into fields, and use the vegetation of agrocoenoses as an additional source of food. By fertilizing the forest and the fields with their faeces the roe deer become a channel of organic matter transfer between these ecosystems (W. Aulak and J. Babińska-Werka, in prep.).

The objective of this study was to determine the range of use of agrocoenoses by roe deer inhabiting small woods surrounded by arable fields. It was attempted to estimate the width of the field-belt that surrounds a forest and provides an additional grazing ground for the roe deer inhabiting that ecosystem. 


\section{Study area}

Experiment were carried out in agrocoenoses surrounding a forest similar in shape to a square about 200 ha in area (Fig. 1). The forest was within the Rogów Experimental Forest Division of Warsaw Agricultural University, situated in central Poland $\left(\varphi-51^{\circ} 48^{\prime} \mathrm{N}, \lambda-19^{\circ} 53^{\prime} \mathrm{E}\right)$. Two forest habitat types dominated there: a mixed fresh coniferous forest-MFCF (Pino-Quercetum typicum Kozł., 1925) and a mixed fresh deciduous forest - MFDF (Tilio-Carpinetum calamagrostietosum Tracz., 1962). The dominant species in the tree stands was the Scots pine Pinus silvestris L., which affected the structure of the ground-cover, providing the grazing ground for the roe deer, whereas the understorey was fairly rich (Aulak, in print).

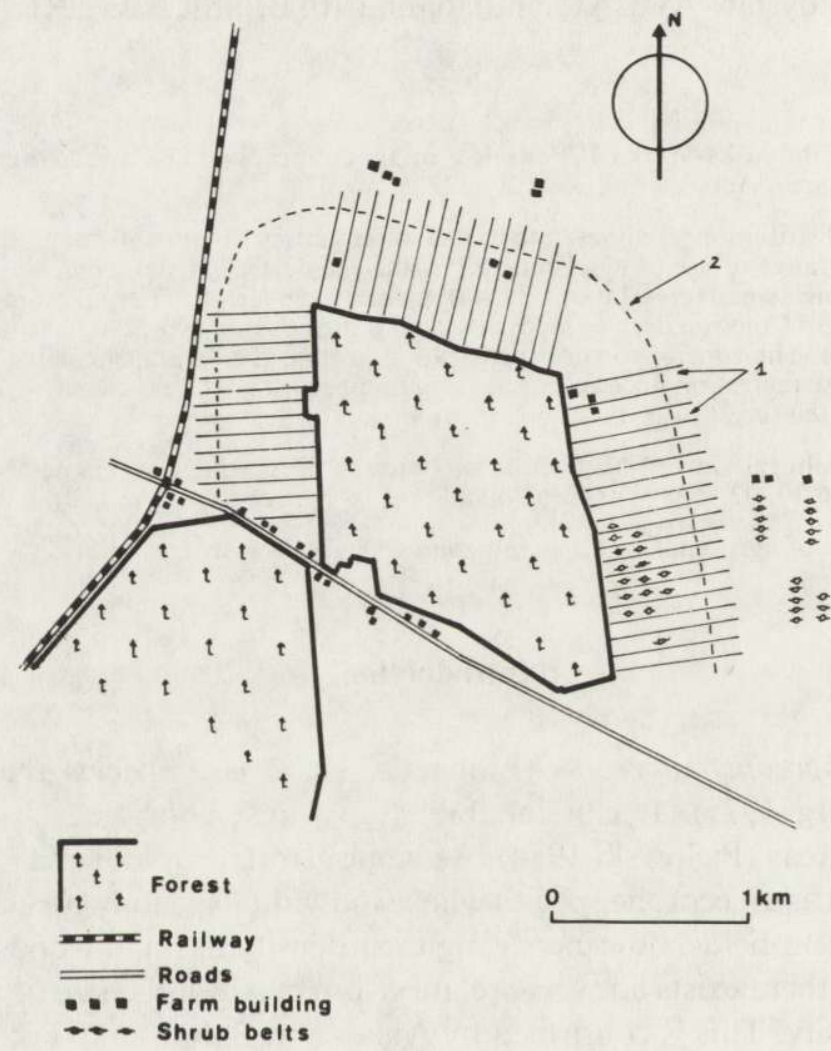

Fig. 1. Outline of the study area. Transects, on which roe deer pellets were collected (1) and estimated distance of roe deer movement into fields (2) are marked.

During the study period (1980 - 1982) the roe deer density was high, from 45 to nearly 62 head per 100 ha forest area (W. Aulak and J. Babińska-Werka, in prep.). With such a high density of individuals, the agrocoenoses bordering on the forest were intensively penetrated by roe deer, notably in periods when the forest ground-cover vegetation was less attractive than the fields which abounded in fresh green cereal or leguminous crops. The length of the field and forest ecotone was about $6 \mathrm{~km}$.

Though the crop-field distribution varied from year to year, the crop species structure remained relatively stable, because of a rather schematic crop rotation. In 1981, the proportions of crops over a belt 
$500 \mathrm{~m}$ wide around the forest were as follows: potatoes $21 \%$, oats $20 \%$, rye $46 \%$, meadows $3 \%$, legiminous plants $1 \%$, wasteland (swamps, thick scrub) $2 \%$, and orchards and gardens (partly fenced) $7 \%$.

Private ownership predominated in the study area. The size of the cultivated beds, rather narrow but long, varied on an average between 0.4 and 3.0 ha, rarely 8 ha. By chance, two beds with the same crop, frequently occurred side by side but belonging to different owners, creating homogeneous stands often exceeding the areas given above. Small stand farming and crop rotation resulted in a mosaic-like crop pattern, varying with time and space. The distances between beds with the same crops were usually small.

The crops penetrated by the roe deer in different seasons were more or less attractive to them. In the period between the end of the autumn field-crop harvesting and the coming-up of winter crops in most of the field areas there was no vegetation that could provide a feeding ground for roe deer, except the vegetation found on the boundary strips and westeland (W. Aulak and J. Babińska-Werka, in prep.).

There were scrub-overgrown boundary strips along the fields surrounding the forest, especially on its eastern side. On the southern side, $50-100 \mathrm{~m}$ from the forest edge, a road ran parallel to the latter, with dwelling-houses and farm-buildings on either side. About $800 \mathrm{~m}$ from the western side of the forest there was a very busy railway line (Fig. 1)

\section{Study methods}

\section{Faeces distribution analyses}

The experiments were carried out in fields surrounding three sides of a forest. No experiments were carried out on the southern side. There was a road near that side of the forest, with peasants' farms located close to it. The existence of another forest complex near by (about $200 \mathrm{~m}$ ) may have caused the penetration of agrocoenoses by the roe deer of both forests. For this reason, roe deer penetration on that side of the forest may have been subject to various disturbances.

To determine the spatial distribution of pellets around the forest, 48 transects, each about $600 \mathrm{~m}$ long and $3 \mathrm{~m}$ wide, and perpendicular to the forest edge, were set up. On the western side 14 transects were up each time, on the northern 15 , on the eastern 19. The reason for the different numbers of transects was different forest-edge lengths (Fig. 1).

Roe deer pellets were counted over every metre of transect length and totalled for $20 \mathrm{~m}$ segments. In 1980 , counting was done twice (in spring and in autumn), in 1981 only in spring, and in1982 in spring and in autumn. The spring counting dates fell at the turn of April, and the autumn ones at the beginning of November. In summer the method could not by used because the crops were too high, and in winter because the snow cover was too thick. The number of faeces pellets found during the whole observation period over a joint transect length of $14,400 \mathrm{~m}$ was 30,528 .

\section{Direct observation of grazing roe deer}

In the period 1979-1983, roe deer grazing in the fields were watched: in spring, autumn and winter mainly from high seats, and in summer, when there were high cereal crops, mainly by stealing close to them. The distance between the forest edge and the grazing roe deer was estimated from a 1:10,000 map of the crop-beds on which roe deer had been sighted. Watching was done from early dawn to late dusk. During a total of 137 watching periods 979 grazing roe deer were recorded.

\section{Results}

Penetration zone established on the basis of analyses of roe deer faeces distribution

Estimation of the quantity of faeces on 48 transects each time comprised 8.64 ha of agrocoenoses, which represented about $3 \%$ of the field belt surrounding the forest. Variations in pellet density with growing distances from the forest edge were assessed. 
Table 1. Distance (in $\mathrm{m}$ ) of roe deer movement into fields situated on different sides of the forest. Distance calculated by linear regression statistics of roe deer pellet distribution. $\mathrm{y}-$ density of roe deer pellets, $\mathrm{x}-$ distance from the forest edge. ${ }^{1} p<0.01,{ }^{2} p<0.05,{ }^{3}<0.10$.

\begin{tabular}{lllc}
\hline Season & Forest side & Linear regression & $\begin{array}{c}\text { Distance from the } \\
\text { forest edge (in m) }\end{array}$ \\
\hline 1980 spring & West & $y=15.87-0.03689 x$ & 483 \\
& North & $y=6.10-0.00342 x^{1}$ & 445 \\
& East & $y=17.47-0.03712 x$ & 483 \\
1980 autumn & West & $y=4.80-0.01342 x^{1}$ & 396 \\
& North & $y=1.36-0.00273 x^{2}$ & 476 \\
& East & $y=1.41-0.00086 x$ & 529 \\
1981 spring & West & $y=0.88-0.00318 x^{1}$ & 354 \\
& North & $y=0.41-0.00020 x$ & 960 \\
1982 spring & East & $y=2.16-0.00631 x^{1}$ & 377 \\
& West & $y=7.13-0.01332 x$ & 474 \\
& North & $y=8.83-0.02118 x^{1}$ & 436 \\
& East & $y=3.42-0.00158 x$ & 1967 \\
& West & $y=0.24-0.00069 x^{2}$ & 425 \\
& North & $y=0.09-0.00020 x$ & 450 \\
& East & $y=1.85-0.00422 x^{3}$ & 457 \\
\hline
\end{tabular}

Table 2. Distance (in $\mathrm{m}$ ) of roe deer movement into fields from the forest edge. Distance calculated by linear regression statistics of roe deer pellet distribution. ${ }^{1} p<0.01,{ }^{2} p<0.05,{ }^{3}<0.10$

\begin{tabular}{llc}
\hline Season & Linear regression & $\begin{array}{c}\text { Distance from the } \\
\text { forest edge (in m) }\end{array}$ \\
\hline 1980 spring & $\mathrm{y}=20.18-0.0456 \mathrm{x}^{1}$ & 443 \\
1980 autumn & $\mathrm{y}=2.64-0.0063 \mathrm{x}^{2}$ & 419 \\
1981 spring & $\mathrm{y}=1.44-0.0037 \mathrm{x}^{1}$ & 389 \\
1982 spring & $\mathrm{y}=8.73-0.0162 \mathrm{x}^{1}$ & 539 \\
1982 autumn & $\mathrm{y}=0.86-0.0020 \mathrm{x}^{3}$ & 430 \\
\hline
\end{tabular}

A separate treatment of each side of the forest was suggested by the physiographic diversity of the terrain, which may have caused differences in roe deer distribution. Regression straight lines were calculated for the faeces density decrease with a growing distance from the forest edge. The highest pellet density was found in zones 100 up to $200 \mathrm{~m}$ from the forest edge. In more distant zones lower densities were recorded. Regression lines were used to estimate the ranges of penetration of agrocoenoses by the roe deer on the assumption that $y=0$ (Table 1). They attained a value of about $500 \mathrm{~m}$. In most cases the greatest ranges of field penetration by roe deer were recorded for the eastern side of the forest (except for 1981). The number of transects on each forest side (14 to 19) proved to be too small for a statistical analysis. Therefore in many cases the values of the regression coefficient " $b$ " proved insignificant (Table 1).

To remove local differences in the roe deer penetration zone, we calculated for 
Table 3. Percentage of roe deer individuals grazing in the fields $0-200 \mathrm{~m}$ from the forest edge.

\begin{tabular}{lccc}
\hline \multirow{2}{*}{ Season } & \multicolumn{3}{c}{ Distance from the forest edge } \\
\cline { 2 - 4 } & $0-100 \mathrm{~m}$ & $101-200 \mathrm{~m}$ & $\Sigma(0-200 \mathrm{~m})$ \\
\hline Spring & 56 & 15 & 71 \\
Summer & 38 & 14 & 52 \\
Autumn & 54 & 29 & 83 \\
Winter & 46 & 22 & 68 \\
\hline
\end{tabular}

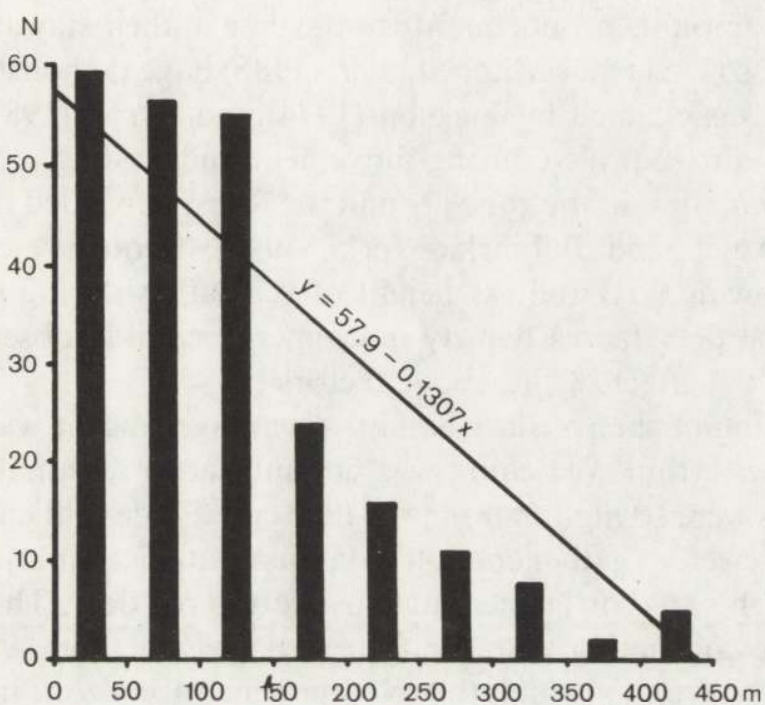

Fig. 2. Number $(\mathrm{N})$ of roe deer observed in the fields in $50 \mathrm{~m}$ wide zones from the forest edge and the distance of movement into fields calculated by linear regression.

each watching date, jointly for all the transects, one straight line of pellet density decrease regression with a growing distance from the forest edge (Table 2). The regression line intersected the axis of abscissae at the value of about $500 \mathrm{~m}$, regardless of the observation date. It may therefore be assumed that this was the width of the zone of roe deer penetration and defecation around the forest.

\section{Penetration zone established on the basis of direct observation of roe deer}

Over $2 / 3$ of the grazing roe deer were found in the belt $0-200 \mathrm{~m}$ from the forest edge (Table 3, Fig. 2). Summer was the only season during which only about $50 \%$ of roe deer grazed in that zone. In single cases roe deer were seen even at distances of over $1 \mathrm{~km}$.

The numbers of roe deer grazing over successive 50 -metre segments, from the forest edge outwards, were used for the calculation of the straight line of regression of the decrease in the number of grazing roe deer with a growing distance from the forest 
edge (Fig. 2). It cut off a field penetration zone $443 \mathrm{~m}$ wide on the horizontal axis. The direction coefficient of the straight line of regression (b) appeared to be statistically significant $(p<0.02)$.

The above data confirmed the existance of an almost 500-metre zone of an intensive use of agrocoenoses by the roe deer.

\section{Discussion}

The analysis of roe deer faeces density was based on the assumption that roe deer defecate faeces in amounts proportionate to the time of their stay at a particular place. Collins and Urness (1981) and Mitchell et al. (1985) have demonstrated that roe deer defecate not only, as claimed by Jackson (1974) and Byron (1981), immediately on rising from their lairs, but also during movement and feeding.

Faeces accumulation in the zone around the forest depended on the rate of faeces disappearance (Aulak and Babińska-Werka 1990), frequency of field cultivation (ploughing, harrowing etc.) and the height of vegetation during pellet counting. To objectivize the roe deer faeces density assessment, suitable observation dates were selected to avoid the effect of the above factors.

Direct watching of the roe deer had an advantage since it was possible to really locate them in the terrain. Watching was not subject to seasonal limitations except when cereal crops were so high that the roe deer could hide in them, not to be seen by the observer. Hovewer, to gather enough data for a statistical analysis many hours had to be spent on high seats, or on stealing close to the roe deer. The method therefore proved more time-consuming than the faeces analysis method.

Both methods have shown that the roe deer penetration zone in fields extended up to about $500 \mathrm{~m}$ from the forest edge. Almost $70 \%$ of the roe deer grazed in fields up to $200 \mathrm{~m}$ from the forest edge. This agrees with Collins and Urness (1981), according to whom the largest quantities of cervids' faeces are found near a forest. The above is also confirmed by Goszczyński's data (1981) from winter roe deer trackings in the same area. Field penetration by the roe deer was found to be most intensive at distances up to $300 \mathrm{~m}$ from the forest edge. The above author found that penetration of agrocoenoses depended on weather conditions. In severe winter weather with much snow the roe deer moved up to $300 \mathrm{~m}$ out of the forest, and when the snow cover was thinner, up to $500-600 \mathrm{~m}$ from the forest edge. Direct watching of grazing roe deer, and observations communicated by hunters of that area, confirmed the presence of individuals that sometimes wandered as far as $2 \mathrm{~km}$ out of the forest under study. The majority of roe deer grazed, however, near the forest edge, and the belt $0-500 \mathrm{~m}$ from the forest edge was intensively penetrated.

The physiographical conditions prevailing in the area around the forest were diverse, resulting in a diversified movement of the roe deer out of the forest. The eastern side differed from the other sides in that it was more favourable to the roe deer. The 
scrub overgrown part of the penetration zone provided an additional shield and refuge for the roe deer, as confirmed by the larger quantities of faeces found there. The presence of scrub overgrown areas at distance up to $400 \mathrm{~m}$ from the forest edge with a simultaneous poor penetration of the area by human beings made it possible for them to move over longer distances. The importance of quiet to roe deer in a hunting round has also been confirmed by Bowden et al. (1969). Mid-field scrub overgrown areas, regardless of their size, also provide attractive retreats for the roe deer (Strändgaard 1972).

The estimated zone of roe deer grazing in agrocoenoses surrounding a forest must be taken into account in the determination of the food sources available to the roe deer inhabiting small forests, and in the assessment of their population density. An estimation of roe deer numbers only in relation to a forest area makes it impossible to assess their density correctly. This seems to be one of the factors responsible for the higher roe deer densities in small forests than large ones.

Acknowledgements: The authors thank Prof. R. Andrzejewski for his valuable criticism during the carrying out of the research. This study was done as part of the programme MR-II-9, coordinated by the Warsaw Agricultural University.

\section{References}

Aulak W. (in print). Runo lasów doświadczalnych SGGW jako potencjalna baza żerowa dla roślinożerców. Zeszyty Naukowe SGGW.

Aulak W. and Babińska-Werka J. 1990. Estimation of the roe deer density based on the abundance and rate of disappearance of their faeces in the forest. Acta theriol. 35: 111-120.

Bluzma P. P. 1976. Vlijanie razmera otdelnych lesov na plotnost naselenija kosul. Ohotniče hozjajstvo $\mathrm{v}$ intensivnom kompleksnom lesnom hozjajstve. Kaunas Giriomp: 44-46.

Bowden D. C., Anderson A. E. and Medin D. E. 1969. Frequency distribution of mule deer faecal pellet group counts. J. Wildl. Manage. 33: 895-906.

Byron H. 1981. Distribution patterns of roe deer (Capreolus capreolus) related to the availability of food and cover. J. Zool., Lond. 194: 271-275.

Collins W. B. and Urness P. J. 1981. Habitat preferences of mule deer rated by pellet-group distribution. J. Wildl. Manage. 45: 969-972.

Ellenberg H. 1975. Neue Ergebnisse der Reh-Ökologie: Zahlbarkeit. Wachstum, Vermehrung. Allgem. Forest Z. 30: 1113-1118.

Goszczyński J. 1981. Use of cartographic method in studies of area penetration by mammals. Wiad. ekol. 27: 253-262. [In Polish with English summary]

Jackson J. E. 1974. The feeding ecology of the fallow deer (Dama dama L.) in the New Forest. Ph. D. thesis, Univ. of Sauthampton.

Mitchell B., Rowe J. J., Ratcliffe P. and Hinge M. 1985. Defecation frequency in roe deer (Capreolus capreolus) in relation to the accumulation rates of faecal deposits. J. Zool., Lond. (A) 207: 1-7.

Pielowski Z. 1984. Sarna. Państw. Wyd. Roln. i Leśne, Warszawa: 1-287.

Strändgaard H. 1972. The roe deer (Capreolus capreolus) population at Kalø and the factor regulating its size. Danish Rev. Game Biol. 7: 1-205.

Received 19 April 1986, accepted 25 May 1990. 